\title{
STUDIES OF SALT AND WATER MOVEMENT IN THE BOL GUINI POLDER
}

CHAD REPUBLIC 
STUDIES OF SALT AND WATER MOVEMENT IN THE BOL GUIN POLDER

CHAD REPUBLIC 
Issued by

INTERNATIONAL INSTITUTE FOR LAND RECLAMATION AND IMPROVEMENT

Bulletin 5

Reprint from Journal of Hydrology,

Vol. I, No. 4, pp. 311-343 


\section{STUDIES OF SALT AND WATER MOVEMENT IN THE BOL GUINI POLDER}

CHAD REPUBLIC

P. J. DIELEMAN

International Institute for Land Reclamation and Improvement

Wageningen, The Netherlands

N. A. DE RIDDER

Institute for Land and Water Management Research

Wageningen, The Netherlands

H. VEENMAN \& ZONEN / WAGENINGEN / THE NETHERLANDS / 1964 
International Institute for Land Reclamation and Improvement

Institut International pour l'Amélioration et la Mise en valeur des Terres

Internationales Institut für Landgewinnung und Kulturtechnik

Instituto Internacional de Rescate y Mejoramiento técnico de Tierras

P.O. BOX 45 / WAGENINGEN / THE NETHERLANDS 


\section{TABLE OF CONTENTS}

\begin{tabular}{|c|c|c|c|}
\hline \multicolumn{3}{|c|}{ page } & \multirow{2}{*}{ Introduction } \\
\hline SeCtion & 1 & 7 & \\
\hline \multirow[t]{8}{*}{ Section } & 2 & 10 & $\begin{array}{l}\text { Some general features of the Bol } \\
\text { Guini polder and its surroundings }\end{array}$ \\
\hline & & 10 & 2.1. Geographical position \\
\hline & & 10 & 2.2. Physiographical features \\
\hline & & 11 & 2.3. Geological Review \\
\hline & & 12 & 2.4. Climate \\
\hline & & 12 & $\begin{array}{l}\text { 2.5. Historical notes on the Bol Gu } \\
\text { polder }\end{array}$ \\
\hline & & 12 & 2.6. Agriculture \\
\hline & & 13 & 2.7. Water and salt regime \\
\hline \multirow[t]{6}{*}{ Section } & 3 & 14 & Subsurface geology \\
\hline & & 16 & 3.1. Upper clay series \\
\hline & & 16 & 3.2. Upper sandy series \\
\hline & & 16 & 3.3. Middle clayey series \\
\hline & & 16 & 3.4. Lower sandy series \\
\hline & & 17 & 3.5. Lower clayey series \\
\hline \multirow[t]{3}{*}{ SECTION } & 4 & 17 & Aquifer characteristics \\
\hline & & 17 & 4.1. Pumping test \\
\hline & & 19 & 4.2. Grain size \\
\hline SECTION & 5 & 19 & Hydro-pedological investigations \\
\hline \multirow[t]{3}{*}{ SECTION } & 6 & 21 & Groundwater movement \\
\hline & & 25 & 6.1. Hydrogeological method \\
\hline & & 26 & 6.2. Water balance \\
\hline \multirow[t]{3}{*}{ SECTION } & 7 & 26 & Groundwater and soil salinity \\
\hline & & 26 & 7.1. Groundwater salinity \\
\hline & & 32 & 7.2. Soil salinity \\
\hline SECTION & 8 & 34 & The salt and water regime \\
\hline \multirow[t]{2}{*}{ SECTION } & 9 & 37 & Final remarks \\
\hline & & 39 & References \\
\hline
\end{tabular}





\section{Introduction}

The Bol Guini polder*) is a small area of a little over 500 hectares situated on the northern shores of Lake Chad some 5 kilometres north of the village of Bol (Figs. 1 and 2).

These northern shores form a dune landscape with elongated sand ridges running closely parallel into the lake. During a relatively recent transgression the lower parts between the ridges were flooded and since then have been regarded as permanently inundated lake inlets. Fine sand, silt and clay

*) The Dutch term 'polder' relates to an area where the water table can be regulated and controlled independently of the water level in the surrounding area. According to this conception the Bol Guini area can hardly be considered a polder, as will be shown below. In line with old Dutch practices, however, a polder is also often thought to be a low-lying area artificially protected against the continuous risk of floods and/or reclaimed from lake or sea. The word is used in this sense in Chad, and, to avoid misunderstandings, it is given no other meaning here. 
particles were deposited in the almost stagnant water of these interdunes.

In recent decades some of the interdunes have been closed off from the lake by constructing small dams which link up two dune ridges at the lake-side. Some years after the enclosure, so much water has evaporated from the enclosed interdune that the lake bottom emerges from the water.

Under these conditions a seepage flow prevails which is due to the difference in level between Lake Chad and the water table in the polder. If

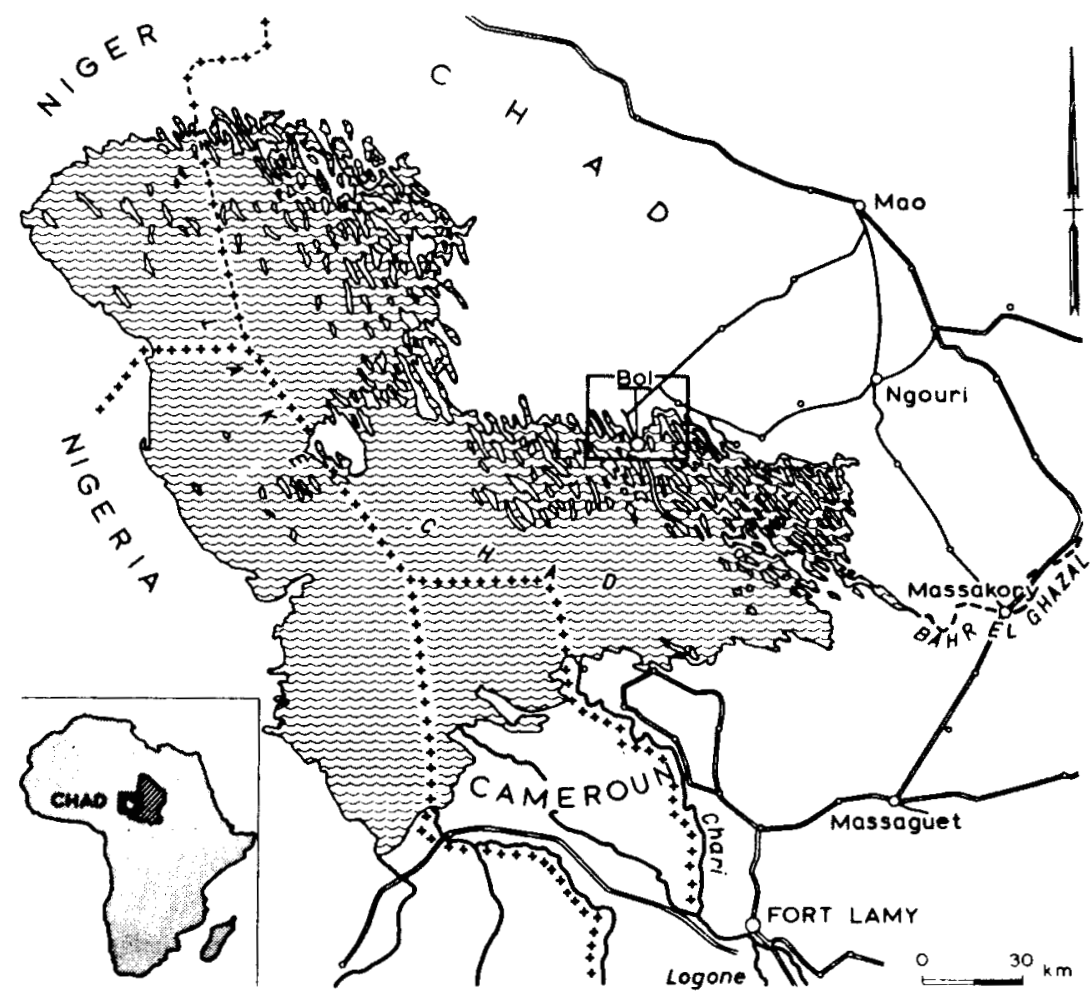

Fig. 1. Lake Chad and its surroundings.

conditions are favourable, a balance is obtained between the seepage flow and the evapotranspiration of the vegetation in the polder. If the groundwater level is at the right depth below the surface of the land, crops can be grown. Crop growth is, however, endangered by the salt content of the seepage water. The fascinating phenomenon of excellent crop growth on groundwater in this arid area south of the Sahara has attracted the attention of many authorities. Studies have been undertaken to extend this type of land and water use to other more or less similar areas within the same region. 
In the Bol Guini polder the combined action of seepage and rainfall in the rainy season often causes the groundwater table to rise to such levels that serious damage to the crop results. On the other hand, the water table may fall after years of little precipitation, resulting in a shortage of water.

Salinity is becoming a serious problem in the major part of the polder.

At the request of the Commission of the European Economic Community (European Development Fund) the authors studied the water and salt move-

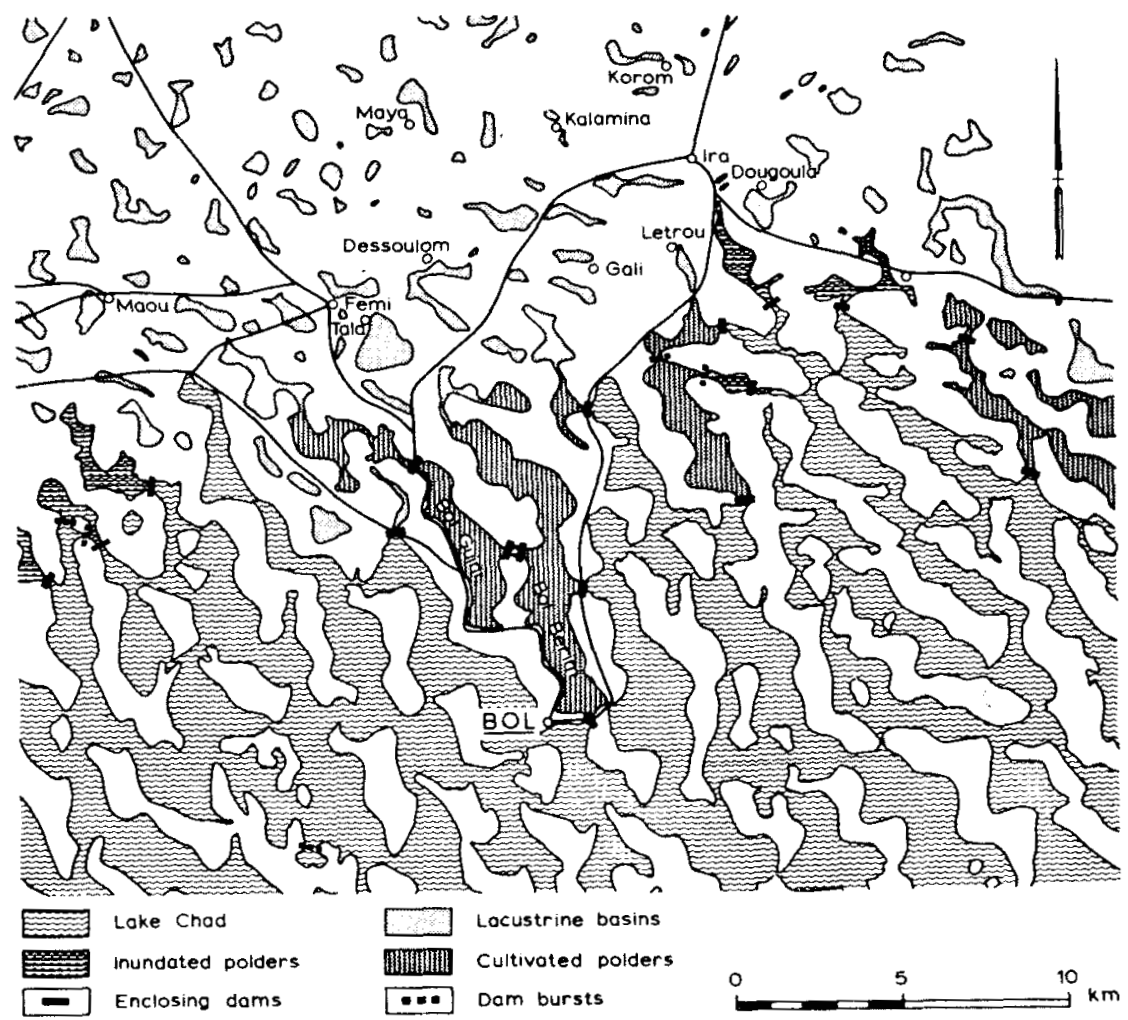

Fig. 2. Part of the northern shores of Lake Chad, including the Bol Guini polder.

ment in the Bol Guini polder in the beginning of 1963 with a view to analysing the present salt and water regime.

They gratefully made use of the data on water tables, salinity conditions, precipitation, etc. recently collected by Pias, Barbery, Bouchardeau, Bouteyre, Guichard, Lefèvre, Lepoutre, the Sogetha Company and others. As these data have a bearing on the upper soil layer, they do not provide a complete picture of the mechanism of the salt and water movement. The authors therefore conducted some hydrological and pedological investi- 
gations in the Bol Guini polder and surrounding dunes by means of shallowand deep borings and piezometers at various depths in some grid lines perpendicular to the circumference of the polder (Fig. 3). Some pumping tests were carried out in the top soil layer and substrata.

In this paper the investigation procedure is described and the results and conclusions are discussed.

The authors are grateful to the European Economic Community for consenting to have some of the results of their investigations published. They are also greatly indebted to Prof. F. Hellinga of the State Agricultural University at Wageningen for the advice and comments given during the investigations and during the processing of the data.

\section{Some general features of the Bol Guini polder and its surroundings}

For background information and a better understanding of the following sections a brief description of the Bol Guini polder and its surroundings is given below.

\subsection{GEOGRAPHICAL POSITION}

Lake Chad extends from $12.2^{\circ} \mathrm{N}$ to $14.3^{\circ} \mathrm{N}$ and from $13.0^{\circ} \mathrm{E}$ to $15.3^{\circ} \mathrm{E}$, the bottom of the lake being about $277 \mathrm{~m}$ above sea level. The village of Bol is situated at a point $13.5^{\circ} \mathrm{N}$ and $14.7^{\circ} \mathrm{E}$ at an altitude of some $290 \mathrm{~m}$ above sea level.

\subsection{PHYSIOGRAPHICAL FEATURES}

Figs. 1 and 2 show Lake Chad with its northern shores, in particular the area of Bol and surrounding districts. Lake Chad, covering an area of approximately $23000 \mathrm{sq} \mathrm{km}$ constitutes a shallow depression in the vast Chad basin ( $2270000 \mathrm{sq} \mathrm{km}$ in extent). The latter is surrounded by mountains and highlands such as the Bauchi-Air-Hoggar mountains in the west, the Tibesti massif in the north, the Ennedi plateau in the east and the Asande saddle in the south.

The partly inundated dune landscape of the northern shores of Lake Chad is characterized by dune ridges which extend generally parallel in a NW-SE direction. The summits of the dunes, which are fairly flat, rise some $10 \mathrm{~m}$ above lake level, i.e. $290-295 \mathrm{~m}$ above sea level, highwater being 281-283 $\mathrm{m}$ above sea level. The dunes are shaped asymmetrically, the western slopes being steeper than the eastern ones.

Lake Chad, which has no outlet, is fed by a few rivers of which the 
Chari - including its tributaries such as the Logone - is the most important. As observed during the period 1933-1957, this perennial stream provides $95 \%$ of the total river supply of some 40 milliard cubic metres per year on the average ${ }^{6}$ ). The peak discharges of the Chari occur in the period September to December. In addition, some $500 \mathrm{~mm}$ of direct precipitation occurs in the lake between July and September.

In the lake, stream discharges and direct rainfall balance evaporation. The particular manner in which discharge and rainfall are distributed over the year, however, causes the water level of the lake to vary by 60 to $100 \mathrm{~cm}$ within one year.

A specific feature of the lake water is its low salt content, at Bol amounting to only 70 milligrams per litre. Elsewhere it may rise to about 400 milligrams per litre.

\subsection{GEOLOGICAL REVIEW}

The Chad basin can be characterized as a tectonic basin which has been filled up with different types of sediments during various geological periods. The total thickness of these sediments is not generally known. In Nigeria, however, during deep drilling the Praecambrian basement had not been reached at $1103 \mathrm{~m}$. Here the "Continental terminal" is $700 \mathrm{~m}$ thick and the marine Cretaceous over $400 \mathrm{~m}^{13}$ ). Neither is very much known of the geological history of the basin during the Quaternary. According to Pias ${ }^{18}$ ) and Barbeau $^{2}$ ) four transgressions during the Quaternary can be distinguished in Lake Chad, each being less important than the preceding one. These transgressions are supposed to be contemporary with the European glaciations. During a glacial period the climate in Africa would have been humid, resulting in a transgression of the lake. During an interglacial period the climate would have been more arid, giving rise to a regression of the lake and to the formation of wind-blown deposits.

The Quaternary sediments encountered in the Chad basin are probably mainly derived from the surrounding mountains (Bauchi, Air, Hoggar, Tibesti, Ennedi and Ouadaii) which consist of a Praecambrian core of granite and metamorphic rocks covered by thick sandstone series of the Cambrian, Silurian, and Devonian. The weathering products of these mountains were transported to the basin by wind action, wadis or rivers, while at present the Chari river is forming a delta in the lake.

Although the volcanic activity in Tibesti probably dates from the Oligocene, important eruptions took place during the Quaternary. Traces of this volcanic activity may therefore be expected in the subsurface sediments of the basin. 


\subsection{CLIMATE}

Climatic conditions in the Bol region may be summarized as follows:

- the annual precipitation as observed from 1946 until now varies from 100 to $700 \mathrm{~mm}$, the average being about $300 \mathrm{~mm}$;

- some $90 \%$ of the total precipitation occurs in the months of July, August and September;

- the annual number of days with precipitation amounts to 25-30;

- the average year temperature is about $29^{\circ} \mathrm{C}$;

- the evaporation of a free water surface, as measured in tanks floating in the lake, may be put at $2300 \mathrm{~mm}$ per year.

\subsection{HISTORICAL NOTES ON THE BOL GUINI POLDER}

The Bol Guini polder came into being in 1951 as a result of the construction of a small dam isolating the existing interdune from the future Bol Berim polder (Fig. 2). In 1954 the water in the enclosed area was evaporated and the bottom of the old lake inlet, now the surface of the Bol Guini polder, emerged from the water.

Owing to exceptionally heavy rains $(717 \mathrm{~mm})$ in 1954 the recently reclaimed polder became inundated again. In 1956, two years after the reinundation, the greater part of Bol Guini was ready for cultivation. At the same time, parts of the Bol Berim polder, which had been enclosed in 1954, emerged.

\subsection{AGRICULTURE}

The soils are of the clay-type. They are rich in organic matter and minerals and have an excellent structure. The main crops are wheat and corn. Wheat is sown after the rainy season, in the period November-December, and is harvested in March-April. After the wheat, corn is sown and harvested in July. Sometimes a third crop is sown in the rainy season, either corn again, or millet ('mil-liqui'). The growing period for the latter is only 45 days until harvest.

Where the groundwater table is sufficiently high (30 to $50 \mathrm{~cm}$ below the surface) capillary rising water covers the requirements of the crop. If the water table is deeper, which is generally the case near the more elevated borders, the 'shadoof'-system of irrigation is practised.

From a well measuring about $1 \mathrm{~m}$ in diameter and 1.5 to $2 \mathrm{~m}$ in depth, water is lifted in a reed basket having a content of 12 to 15 litres. The lifting is facilitated by a lever 
device with a clay counterweight. One man can supply from one well 1.5 to 2 litres per second, which means in practice a required well density of 6 to 8 wells per hectare. The lifted basket is emptied into small ditches built in levees and is then applied to unit areas of some $1.5 \mathrm{~m}^{2}$ ('carrés').

Depending on the elevation of the actual groundwater tables, the acreages thus irrigated differ from year to year.

The cultivated crops grow remarkably well. It is quite understandable that in this arid region all efforts are concentrated on the preservation of the cultivated areas by prevention of waterlogging and salinization, and that great efforts are made to expand areas with similar land and water development.

\subsection{WATER AND SALT REGIME}

The level of the groundwater table is the result of the action of evapotranspiration, precipitation and seepage. Seepage is the result of the difference in level between Lake Chad and the groundwater table. The following information was obtained from Pias and Barbery 22, 23) concerning the groundwater tables.

- The groundwater table mainly fluctuates between 0.25 and $1.00 \mathrm{~m}$ below the surface of the land.

- The highest groundwater table occurs in the rainy season (July-September). At some periods the water table reaches the surface, lower-lying parts becoming inundated. If precipitation exceeds the average amount of $300 \mathrm{~mm}$ per year, as happened in 1959 and 1961 (520 and $504 \mathrm{~mm}$ respectively), prolonged inundation of large areas results.

- The water table falls gradually after the rainy season is over. The rate of fall depends both on evapotranspiration and on the water level of Lake Chad. If this level is high, the amount of seepage will be relatively great and, as a consequence, the fall relatively slow.

- The fall of the water table continues at an even rate until March-April. From then on, the fall will decrease, may cease or may even change in a slight rise in level, owing to a reduced transpiration since at this time the water plants start to die.

The same authors draw attention to the increasing salt content of the upper soil layers, which is becoming a matter of great concern. In December 1960 , two months after the end of the rainy season, large tracts had a salt content corresponding to an EC value of 4-8 millimhos per $\mathrm{cm}^{*}$ ) in the

*) Salt contents are often expressed in terms of electrical conductivity (EC) which is measured in mhos per $\mathrm{cm}$ (reciprocal ohms). For reasons of convenience the subunits, millimhos per $\mathrm{cm}\left(10^{-3} \mathrm{mhos} / \mathrm{cm}\right)$ and micromhos per $\mathrm{cm}\left(10^{-6} \mathrm{mhos} / \mathrm{cm}\right)$, have been 
upper $20 \mathrm{~cm}$ of the soil. The salt present is believed to originate from two sources. Firstly, the salt contained in the lake water remains as a residue after the evaporation of the water behind the enclosing dam. Secondly, lake water seeps into the polder and, as there is no outlet, the salt thus supplied also contributes to soil salinity.

\section{Subsurface geology}

The subsurface geology of the polder was explored by making a number of deep drillings (T1-T5) varying in depth from 50 to $100 \mathrm{~m}$ and a number of shallower drillings. Additional drillings of varying depths were made in the surrounding dunes (Fig. 3).

Since the sediments encountered are poor in fossils, it is difficult to establish accurate time-stratigraphic boundaries. The stratigraphic units identified below are mainly rock units relatively consistent in lithology; it should also be borne in mind that in some cases time boundaries may traverse these units.

Although heavy minerals generally cannot be used for dating sedimentary layers, they do occur in practically all sediments and may contribute to paleogeographical conclusions. For that reason the composition of the heavy mineral residue of the sand samples from a few deep drillings was determined. It appeared that this composition was fairly uniform down to a depth of $70 \mathrm{~m}$. The principal heavy minerals in the sand grade from 50 to 500 microns are zircon, tourmaline, epidote and staurolite, of which zircon with 50 to $60 \%$ is very abundant.

This heavy mineral association indicates that all these sands are mainly derived from old, decomposed rocks. The most probable region of provenance may therefore be, the mountain regions in the north-east (e.g. Tibesti), where such old rocks as Cambrian, Silurian and Devonian sandstones are widespread. In this connection it should be noted that all samples examined also contained a low percentage of volcanic minerals (titanite, augite, basaltic hornblende), which is sufficient evidence that Tibesti with its Quaternary volcanoes (Emi Koussi) is the most probable region of provenance.

In the subsurface of the polder and surrounding dune areas the following stratigraphic units can be distinguished (Fig. 4).

introduced ${ }^{27}$ ). In this paper soil salinity relates to the solution extracted from a soil at its saturation percentage. For the salt conditions of the Bol Guini polder the EC figure in millimhos may be converted into grams per litre of moisture by multiplying it by a factor of $0.6(\mathrm{EC}=10 \mathrm{millimhos} / \mathrm{cm}$ corresponds to a salt content of 6 grams per litre). 


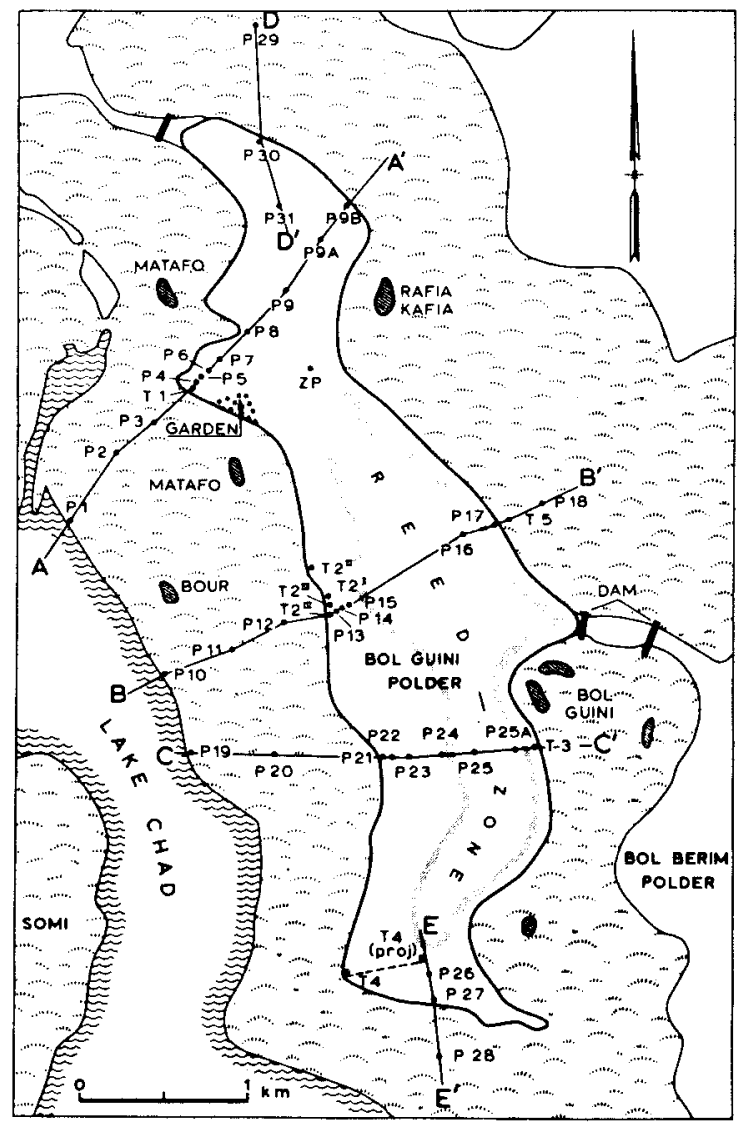

Fig. 3. Grid lines with borings in the Bol Guini polder and surrounding dunes.

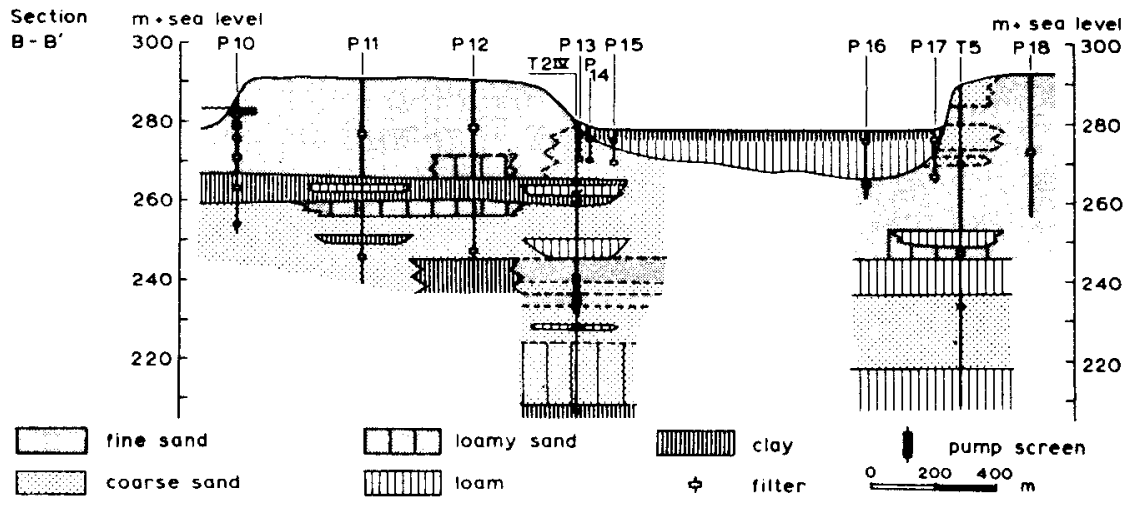

Fig. 4. Geological section of grid line B-B'. For location, see Fig. 3. 


\subsection{UPPER CLAY SERIES}

This series was formed during the latest transgression of the lake when the water penetrated the depressions between the dune ridges. At first mainly fine sand and silt were deposited, but in later stages the deposition of clay became predominant. Parts of these sediments are rich in organic material.

In consequence of the asymmetrical shape of the dunes, the thickness of this clayey series increases in an easterly direction to a maximum of $12 \mathrm{~m}$.

\subsection{UPPER SANDY SERIES}

This series is found at the basis of the covering clay series and extends to a depth of approximately $15 \mathrm{~m}$ below the surface of the land $(=264 \mathrm{~m}$ above sea level). It forms part of the present dune system and probably originated during the latest regression of the lake.

The grain size of the sands generally varies between 105 and 300 microns, indicating their aeolian character.

\subsection{MIDDLE CLAYEY SERIES}

At the basis of the upper sandy series a clayey-loamy series is found at many places in the polder and the surrounding dunes. In the polder it extends from 15 to $21 \mathrm{~m}$ below the surface of the land. In a few borings such as P16, P18, T5, P2 and P29, this series was not found.

The series consists of grey sandy loam, silty loam and clay. A thermal diffraction analysis revealed a montmorillonite type of clay, viz. nontronite.

This sediment probably indicates the final stage of a Pleistocene lake deposit (3rd transgression phase?) which filled up a depression of the dune landscape at that time.

\subsection{LOWER SANDY SERIES}

At a depth of 21 to $70 \mathrm{~m}$ ( 258 to $209 \mathrm{~m}$ above sea level) a sandy series is found, consisting of fine and coarse sands with concretions of lime. The grain size of these sands varies from 150 to 500 microns, but sometimes particles are found with diameters from 1000 to 1500 microns, indicating the fluvial environment of the deposition. On the other hand, some of the sands are characteristic of wind-blown sands.

This series also contains several clay and loam layers having varying thicknesses and occurring at various depths. These layers are lenticular in shape. In some cases shales were found. This material was deposited during 
one of the older transgressions of the lake during the Pleistocene, but it is difficult to decide from what period of the Pleistocene.

\subsection{LOWER CLAYEY SERIES}

At the basis of the lower sandy series, at a depth of approximately $70 \mathrm{~m}$ (209 $\mathrm{m}$ above sea level), a clayey series is found, consisting of shale, clay and loamy sand. It can be considered to be the impervious basement which probably extends under the entire region. In boring $\mathrm{T} 4$, the upper part of this series consists of fairly compact loamy, coarse sands, gradually passing into shale. At a depth of $103 \mathrm{~m}$, the basis of these shales had still not been reached, so that their thickness is more than $30 \mathrm{~m}$.

More or less the same profile has earlier been found in a $350 \mathrm{~m}$ deep boring in Fort-Lamy, where a clayey series with sandy intercalations occurs from 60 to $280 \mathrm{~m}$ below the surface of the land. For this reason it is assumed that the thickness of this lower clayey series in the Bol Guini polder may be considerably greater than $30 \mathrm{~m}$.

To sum up it can be stated that the subsurface of the polder consists of two sandy series (aquifers) which are only partly separated by a semipervious clay series (aquiclude). The upper aquifer is covered by a clay series in the polder only. The lower aquifer is underlaid by an impervious basement of compact loamy sand, clay and shale.

\section{Aquifer characteristics}

Geological investigations have revealed the occurrence of two aquifers through which groundwater flows in the direction of the polder (see Section 6). For the dune stretch it is assumed that this groundwater flow is chiefly horizontal.

The transmissibility data of these aquifers were derived from a pumping test and from the grain size of the sands.

\subsection{PUMPING TEST}

The pumping test was carried out in the lower aquifer near boring T2. In addition to the pumping well, $\mathrm{T} 2^{\mathrm{IV}}$, three observation wells, $\mathrm{T} 2^{\mathrm{III}}, \mathrm{T} 2^{\mathrm{I}}$ and $\mathrm{T} 22^{\mathrm{II}}$, were dug at distances of $25 \mathrm{~m}, 100 \mathrm{~m}$ and $300 \mathrm{~m}$, respectively, from the pumping well. In each of these wells, three or four observation filters were installed at various depths (length of the filter $1 \mathrm{~m}$ ). The pumping screen in well $\mathrm{T} 2^{\mathrm{IV}}$ was installed from 38.00 to $48.70 \mathrm{~m}$ below the surface.

Pumping was continued for 15 hours with a constant discharge of $16 \mathrm{~m}^{3}$ 
per hour. At first the drawdowns in the various piezometers were measured very frequently, but after a certain time measurements were carried out at intervals of approximately one hour. It appeared that after 15 hours of pumping the drawdowns were nearly constant; in other words the stage of equilibrium had more or less been reached by that time.

As small drawdowns in the phreatic level were observed during the pumping in the lower aquifer, it could be concluded that the groundwater in this aquifer is of a semi-artesian nature.

For the interpretation of the test, the method introduced by De Glee ${ }^{14}$ ) was applied. For these flow conditions De Glee derived the following formula:

where:

$$
h_{\mathrm{m}} \frac{2 \pi k D}{Q}=K_{0}\left(\frac{r}{\sqrt{k D \cdot c}}\right)
$$

$h_{\mathrm{m}}=$ maximum drawdown (in $\mathrm{m}$ ) in an observation well at distance $r$ (in $\mathrm{m}$ ) from the pumping well;

$Q=$ discharge of the pumped well (in $\mathrm{m}^{3} /$ day);

$k D=$ transmissibility of the aquifer (in $\mathrm{m}^{2} /$ day);

$K_{0}=$ modified Bessel function of the 2 nd kind and of zero order

$\sqrt{k D \cdot c}=L=$ leakage factor (in $\mathrm{m}$ );

$c=D^{\prime} / k^{\prime}=$ vertical resistance (also called 'leakage coefficient') of semiconfined layer (in days). $D^{\prime}$ and $k^{\prime}$ are the thickness and the vertical hydraulic conductivity of this layer, respectively.

The type curve is constructed on double logarithmic paper by plotting $K_{0}(x)$ versus $x$. The values of $K_{0}(x)$ for a wide range of $x$ are given by De Glee ${ }^{15}$ ), Hantush ${ }^{17}$ ) and Schoeller ${ }^{28}$ ). Values of drawdown are plotted against distances to the pumped well on logarithmic paper with the same scale as that used for the type curve. The observed data curve is superimposed on the type curve, keeping the coordinate axes of the two curves parallel, and adjusted until a position is found where most of the plotted points of the observed data fall on a segment of the type curve. The distance between the two horizontal coordinate axes gives:

$$
\frac{Q}{2 \pi k D}
$$

The distance between the vertical coordinate axes gives:

$$
L=\sqrt{k D \cdot c} .
$$

The transmissibility of the lower aquifer follows from

$$
\frac{Q}{2 \pi k D}=0.04
$$

or

$$
k D \approx 1565 \mathrm{~m}^{2} / \mathrm{day}
$$


The vertical resistance of the clay series, which covers the aquifer, follows from $\sqrt{k D c}=300$ or $c=57$ days.

\subsection{GRAIN SIZE}

The transmissibility of the lower aquifer in boring $\mathrm{T}_{2}{ }^{\mathrm{I}}$ was also derived from the grain size of the sands, many samples of which were collected during the drilling. As a result of the calculations a value of $1525 \mathrm{~m}^{2} /$ day was found, which is in very good agreement with that derived from the pumping test.

The transmissibility values of the upper and lower aquifers near borings T1, T3, T4 and T5 were calculated from the grain size of the sands, which were sampled at these places in detail. Results as indicated in Table 1 were obtained.

TABLe 1

Transmissibilities of the aquifers according to calculations made from the grain size data of the sands

\begin{tabular}{ccc}
\hline \multirow{2}{*}{ Boring } & \multicolumn{2}{c}{$k D$ values in $\mathrm{m}^{2} /$ day } \\
\cline { 2 - 3 } & upper aquifer $(5-15 \mathrm{~m})$ & lower aquifer $(21-70 \mathrm{~m})$ \\
\hline T1 & 210 & 1625 \\
T2 & 280 & 1525 \\
T3 & 180 & 1420 \\
T4 & 335 & 1920 \\
T5 & & 675 \\
\hline
\end{tabular}

\section{Hydro-pedological investigations}

In Section 3 reference was made to the occurrence of an upper clay series deposited during and since the latest transgression phase. This layer is of particular importance to agriculture. Any water control measures that may be taken will be closely bound up with the hydrological properties of this layer, which, therefore, will be discussed in more detail.

The results of some seventy shallow borings have made it clear that the upper clay series generally consists of three layers which differ widely in hydrologic characteristics (Fig. 5). Deviations from the general pattern may occur near the more elevated border zones.

The top 40 to $80 \mathrm{~cm}$ of soil generally consists of clay deposits. According to Pias and Barbery ${ }^{22}$ ), the organic matter content is high and amounts to 10 to 20 per cent in the upper $40 \mathrm{~cm}$. The hydraulic conductivity is not known exactly but may be estimated at a few metres per day. The infiltration 
rate is as high as 50 to $100 \mathrm{~mm}$ per hour ${ }^{29}$ ), which means that special measures are required in irrigation agriculture in order to avoid excessive percolation losses.

The top soil is underlaid by a layer of heavy clay which is 1.5 to $2 \mathrm{~m}$ thick, and has large cracks and fissures. As the main part of this layer, since reclamation, is found below the phreatic level, the fissures point to a dry period in the geological past. The levels of Lake Chad as given by

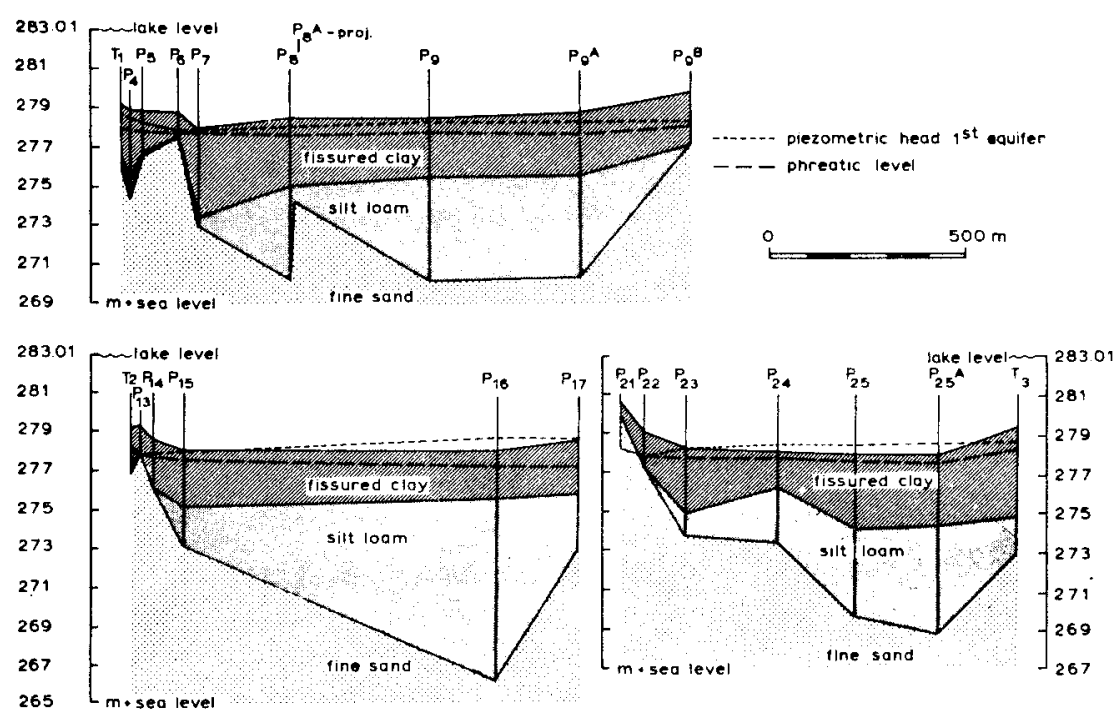

Fig. 5. Schematic soil profiles and piezometric surfaces of grid lines $A-A^{\prime}, B-B^{\prime}$ and C-C'. For location, see Fig. 3.

Bouchardeau and Lefèvre ${ }^{6}$ ) do not, however, indicate the occurrence of such a period within the last century.

At any rate, the non-reversible nature of the desiccation does not appear to be open to doubt. The hydraulic conductivity was obtained from pumping tests, since it became clear that such methods as Hooghoudt's ${ }^{3}$ ) and the piezometer method could not provide a satisfactory result. It proved to be simply impossible to lower the groundwater table using the appropriate equipment.

This in itself, together with the fact that the water levels in the shadoofs had not changed after water had been lifted continuously for a number of hours at a rate of 60 to $100 \mathrm{l} / \mathrm{min}$, pointed to very high hydraulic conductivities. Using an auger hole having a diameter of $15 \mathrm{~cm}$ and reaching to the impervious floor underlying the cracked clay layer, a lowering by 2 to $8 \mathrm{~cm}$ could be achieved if water was removed at a rate of $31 / \mathrm{sec}$. Elaboration of 
the observed data (such as changes of water levels in 4 or 5 piezometers installed at various distances from the auger hole) according to Thiem ${ }^{28}$ ) showed the hydraulic conductivity to be extremely high. Four pumping tests carried out near P26, P24, P8 and at 300 m east of the Matafo garden (Fig. 3) yielded conductivities of $900,5000,2500$ and $2000 \mathrm{~m} /$ day, respectively.

Apart from a certain transition layer, a grey-black silt loam layer occurs between the cracked clay and the upper sandy series. Analysis of a few soil samples for particle size distribution showed the following results: $18 \%$ smaller than 2 micron, $75 \%$ between 2 and 50 microns and $7 \%$ larger than 50 microns. The thickness of this layer increases in an easterly direction until some 150 to $250 \mathrm{~m}$ from the eastern border where it reaches a maximum of 5 to $10 \mathrm{~m}$. Near the western border a zone is found where the silt loam is either absent or very thin (Fig. 5). This zone varies in width from some 50 to $100 \mathrm{~m}$.

The silt loam looks like mud and is structureless when saturated with moisture. The hydraulic conductivity observed visually was confirmed by provisional tests and may be as low as $1 \mathrm{~cm} /$ day. Consequently, the vertical flow resistance, which varies in direct proportion to the thickness of the silt-loam layer, will be relatively high (500 to 1000 days).

Fig. 5 also shows the piezometric surface measured in the upper sandy series underlying the resistance layer, and the phreatic surface. The difference between the two levels appears to be related to the thickness of the resistance layer: when the thickness decreases the differences also decrease.

Deviations in this general behaviour develop if other resistance layers occur as lenses in strata above and/or below the silt loam. In the western border zone, such layers are sometimes found in the sand stratum. On the other hand, small variations in the hydraulic conductivity of the silt loam will also result in differences in the vertical resistance of this important layer.

It will be obvious that the silt loam resistance layer constitutes a flow barrier between the cracked clay layer above and the sand stratum below. The link between the latter two layers is largely maintained by means of a "gap" in the western border zone. Here the resistance layer is either only very thin or simply absent and the greater part of any vertical water movement will take place in this zone.

\section{Groundwater movement}

The direction and intensity of the groundwater flow were ascertained from three groundwater contour maps showing, namely:

- the phreatic surface, 
- the piezometric surface of the upper aquifer,

- the piezometric surface of the lower aquifer.

Fig. 6 shows the contour map of the phreatic surface. The groundwater appears to flow from the lake through the dune area to the polder. In the polder itself water flows from west to east with a flow component in the

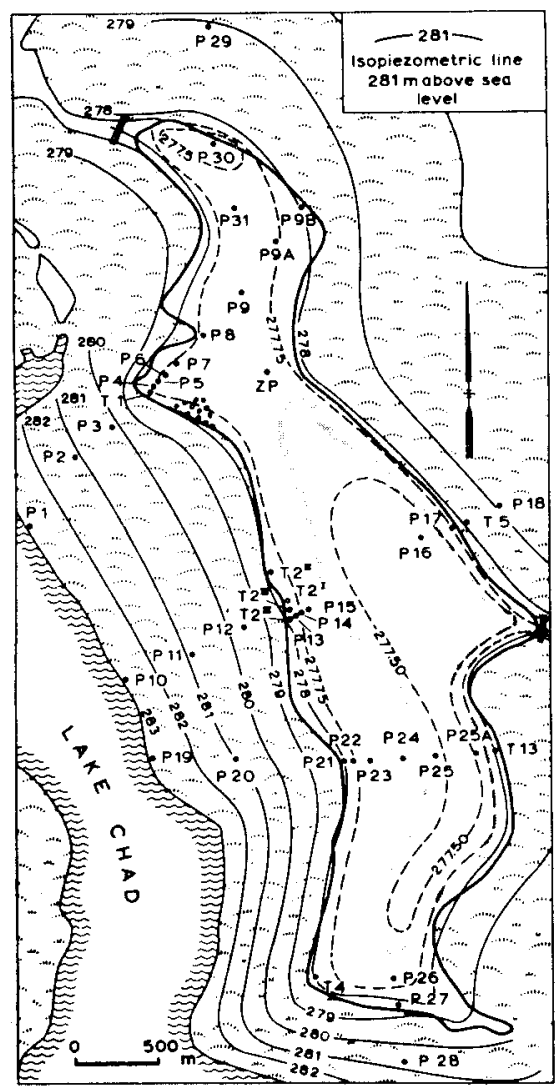

Fig. 6. Contour map of the phreatic level, March 1963.

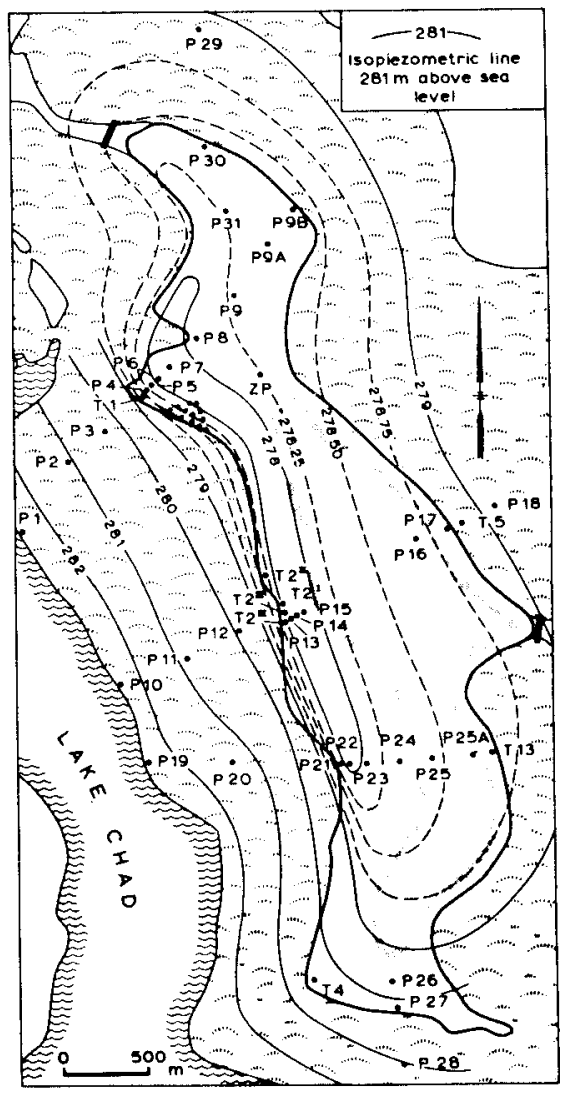

Fig. 7. Isopiezometric map of the upper aquifer, March 1963.

direction of the double dam between Bol Guini and Bol Berim. The gradient in the polder is much smaller than in the dune area.

The isopiezometric map of the upper aquifer at a depth of approximately $10 \mathrm{~m}$ is shown in Fig. 7. Owing to the presence of a relatively impervious silt-loam layer at the basis of the upper clay series in the polder, this aquifer shows artesian characteristics (Fig. 5). At many places the piezometric head 
rises to $1 \mathrm{~m}$ or even more above the surface of the land (278 to $279 \mathrm{~m}$ above sea level). The map shows a groundwater flow from the lake through the dunes to the polder, but there are indications that in the greater part of the polder the groundwater in this aquifer flows in a westerly direction, i.e. contrary to the direction of flow in the cracked covering clay layer (Fig. 6). The lowest piezometric heads were found in a narrow zone between observation wells P7 and P22 in the western part of the polder. The greater part of the seepage water appears therefore to flow up towards the surface soil layers through this narrow zone. This phenomenon coincides with the partial or complete absence of the silt-loam layer (resistance layer), as reported in Section 5 with regard to the same area. A rather specific case arises near T4 where a small slow-moving spring wettens the soil surface of a small area.

The seepage water when it arrives at the surface soil layers, starts flowing horizontally through the fissured clay layer and over the silt-loam resistance layer in an easterly direction. The hydraulic gradient required for such a flow was found within the grid lines B and C (Fig. 5) and may also be derived from data supplied by Pias and Barbery ${ }^{22,23}$ ). Grid line A does not show potential differences, probably because of irregularities in the profile. Near P8, for instance, the sandy permeable subsoil rises sharply to the fissured layer, causing the vertical flow resistance there to be relatively small.

The number of observation wells penetrating the lower aquifer at a depth of between 20 and $70 \mathrm{~m}$ is relatively small and, in consequence, a representative isopiezometric map of the groundwater in this deep-lying aquifer can hardly be established. If the available data are plotted on a map, however, it appears that there is an intensive groundwater flow from the lake in the direction of the polder (Fig. 8). In the polder itself the gradient is very small, but in the absence of data it can not be decided whether the flow here is in an easterly or a westerly direction. In certain parts of the polder the middle clay series (at a depth of $15-21 \mathrm{~m}$ ) is absent, and for that reason this lower aquifer can be characterized as a leaky aquifer. Groundwater from this aquifer will flow through the gaps in the impervious clay layer and will penetrate the polder as seepage water.

From the above it will be clear that the seepage flow in the Bol Guini polder as sketched in Fig. 9 varies from place to place and is fully dependent on subsurface geological conditions.

To determine the contribution of the seepage flow to the consumptive use of the crops the intensity of the seepage flow had to be calculated. Two methods were applied, viz.: the hydrogeological method, and the water balance method. 


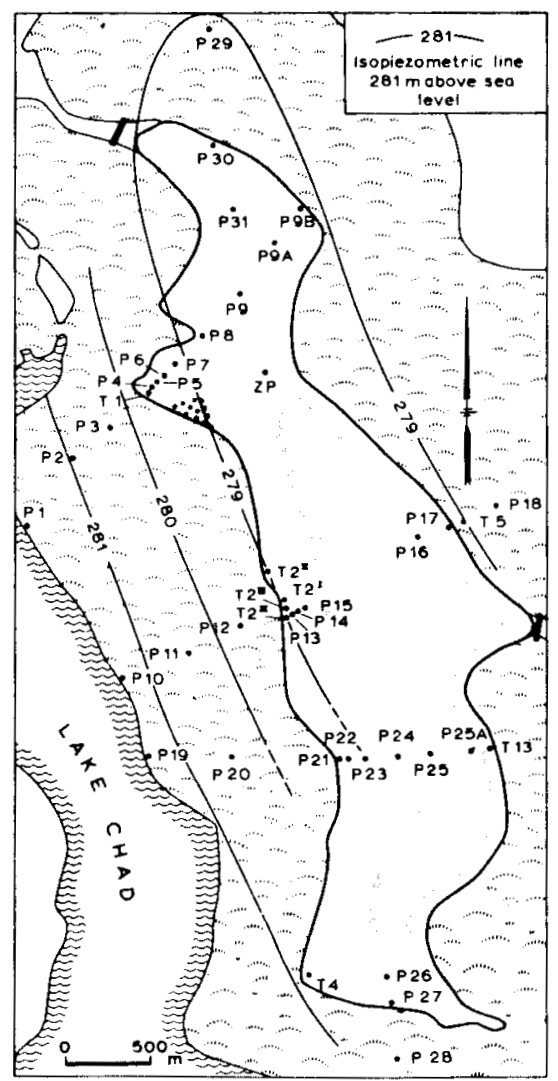

Fig. 8. Isopiezometric map of the lower aquifer, March 1963.

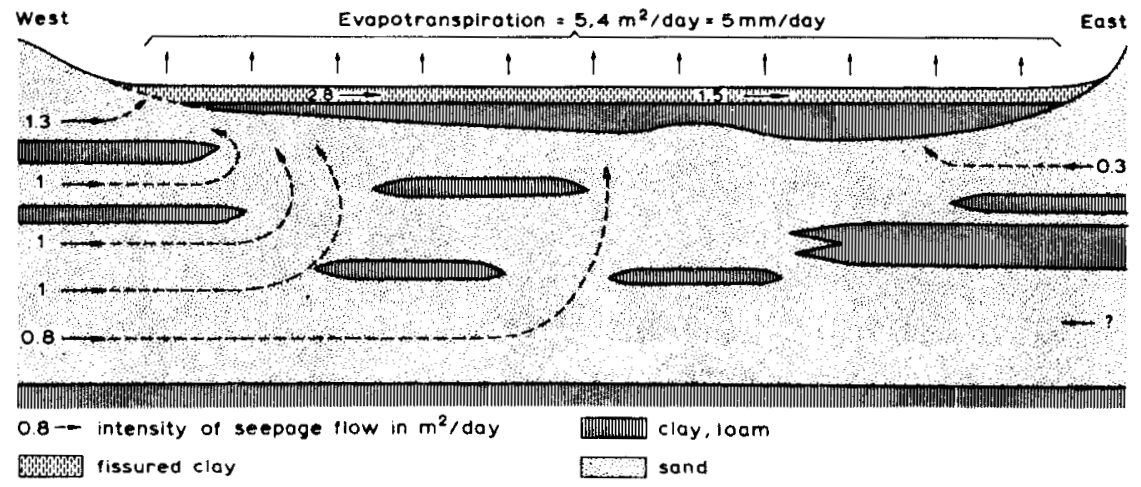

Fig. 9. Sketch of direction and intensity of the seepage flow, March 1963. 


\subsection{HYDROGEOLOGICAL METHOD}

From the hydrogeological point of view, the total seepage flow $(Q)$ is composed of a quantity of flow $\left(q_{1}\right)$ transmitted by the upper aquifer and another $\left(q_{2}\right)$ transmitted by the lower aquifer.

\subsubsection{Upper aquifer}

To calculate the quantity of seepage water $\left(q_{1}\right)$ transmitted by this aquifer, the circumference of the polder was divided into a number of units of length $(L)$. The corresponding dune strips are characterized by a certain groundwater gradient $(\mathrm{d} h / \mathrm{d} x)$ and a certain transmissibility $(k D)$. The length of these units can be measured and, if we ignore the radial part of the flow in the northern and southern parts of the polder, the intensity of the seepage flow can be calculated as follows:

$$
q_{1}=L_{1} \frac{\mathrm{d} h_{1}}{\mathrm{~d} x_{1}} k_{1} D_{1}+L_{2} \frac{\mathrm{d} h_{2}}{\mathrm{~d} x_{2}} k_{2} D_{2}+L_{3} \frac{\mathrm{d} h_{3}}{\mathrm{~d} x_{3}} k_{3} D_{3}+\ldots
$$

Substitution of the known values in this formula gives:

$$
\begin{aligned}
& \quad q_{1}=\frac{1650}{800} \cdot 210+\frac{3550}{1320} \cdot 250+\frac{3200}{1440} \cdot 180+\frac{1150}{320} \cdot 335+\frac{3800}{230} \cdot 280 \\
& q_{1}=7340 \mathrm{~m}^{3} / \text { day. }
\end{aligned}
$$

\subsubsection{Lower aquifer}

To calculate the quantity of seepage water $\left(q_{2}\right)$ transmitted by this deep aquifer, the polder can, in the first instance, be divided into a western and an eastern part. The most important seepage flow, occurs in the western part, where the mean groundwater gradient amounts to $\frac{1}{450}$.

The transmissibility of this aquifer is $1700 \mathrm{~m}^{2} /$ day which is the mean $k D$ value of wells $T 1, T 2$ and $T 4$ located along the west side of the polder. The quantity of seepage water entering the polder along the west side over a length of approximately $6000 \mathrm{~m}$ amounts to:

$$
q_{2}=\frac{6000}{450} \cdot 1700=22667 \mathrm{~m}^{3} / \text { day. }
$$

The time available did not permit a determination to be made of the piezometric heads of the lower aquifer on a more regional scale. As far as available data permitted, the analysis showed a marked groundwater flow from Lake Chad to the polder and little, if any, groundwater flow in the opposite direction.

If we therefore ignore this seepage flow from the east, the total intensity 
of seepage flow $(Q)$ for the polder, covering an area of 531 hectares, for the month of March 1963, being the period for which the groundwater maps are established, amounts to

$$
Q=\frac{7340+22667}{5310000} \times 1000=5.6 \mathrm{~mm} / \mathrm{day} .
$$

\subsection{WATER BALANCE}

The calculation of the intensity of seepage by the water-balance method is based on a balance between evaporation, on the one hand, and rainfall plus seepage flow, on the other, assuming that the situation remains fairly constant over a number of years. Evaporation has been determined for some years by such means as the floating-pan method (Bacs Colorado) in Lake Chad. An average annual total evaporation of about $2300 \mathrm{~mm}$ has been obtained from the observations $6,5,22,29$ ).

The relation between the values obtained from Bacs Colorado (Lake Chad) and the evaporation in the polder depends on the extent to which the polder is covered with vegetation, on the amount of water available, on the height of growth and also on the extent to which advective energy plays a role. On the one hand, evaporation in some thickly vegetated parts of the polder at certain stages of growth may be taken as 1.1 to 1.3 times the evaporation of the Bacs Colorado. On the other hand, there are certainly other parts of the polder where growth in some periods is considerably less intensive and where evaporation is, consequently, less than that of the Bacs Colorado. We therefore feel that we can adhere to an annual figure of $2300 \mathrm{~mm}$ for average potential evaporation.

The average rainfall for the period 1946-1960 was about $300 \mathrm{~mm}$ (Sogetha Report). The average annual total seepage supply is therefore about $2000 \mathrm{~mm}$, giving a figure of $5.4 \mathrm{~mm}$ for the average daily seepage intensity.

The results of the calculations obtained by methods 6.1. and 6.2. show a large measure of agreement. It should be pointed out, furthermore, that the seepage intensity calculated according to method 6.1. applies for the month of March 1963. The difference between the level of Lake Chad and the groundwater level was above average in that month.

\section{Groundwater and soil salinity}

\subsection{GROUNDWATER SALINITY}

\subsubsection{Salt concentration}

It has already been noted that the water of Lake Chad has a very low 
salt content. Near the village of Bol EC values of some 120 micromhos $/ \mathrm{cm}$ (70 mg per litre) were measured.

The shallow groundwater in the polder appears to be much more saline than the lake water, as is shown in Fig. 10. The mean salt concentration as measured in shadoofs and observation filters at a depth of 2 to $3 \mathrm{~m}$ amounts to some 1400 micromhos $/ \mathrm{cm}$.

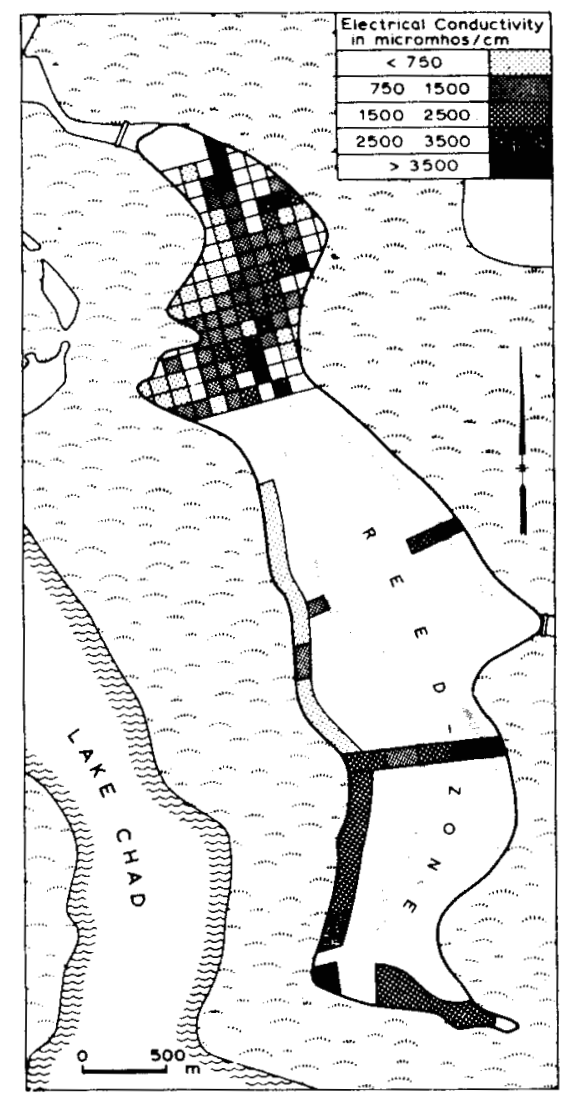

Fig. 10. Electrical conductivity of groundwater in shadoofs and shallow piezometers, March 1963.

This value does not include the groundwater in the reed-covered parts of the polder, where no shadoofs are found. There are, however, sufficient indications that the salinity here considerably exceeds the average (see below). It is worthy of note that the shallow groundwater in the southern part of the polder is much more saline than the groundwater in the central and northern parts. Moreover, salinity appears to increase from west to 
east, as is explained by the easterly flow direction in the fissured clay layer (see also Section 8).

The groundwater from the upper aquifer (at a depth of approximately $10 \mathrm{~m}$ ) also has a much higher salt content than the lake water (see Table 2). The lowest salt concentrations are found in the dune areas $(\mathrm{EC}<500$ micromhos $/ \mathrm{cm}$ ). In the polder, the highest salt concentrations occur in the southern parts ( $\mathrm{T} 3 ; \mathrm{EC} \approx 3700$ micromhos $/ \mathrm{cm}$ ).

The lower aquifer samples also show a great variation in salt content although there are only a few of them. The EC values increase in a south easterly direction, the highest value being found at well $\mathrm{T} 3(\mathrm{EC}=5600$ micromhos $/ \mathrm{cm}$ ).

It is worth noting that in well $\mathrm{T} 4$ the groundwater from the lower aquifer was found to be less saline $(\mathrm{EC}=1600$ micromhos $/ \mathrm{cm}$ ) than that from the upper aquifer $(\mathrm{EC}=3100$ micromhos $/ \mathrm{cm})$. As the spring water close to this well was found to have EC values varying from 3000 to 4000 micromhos/ $\mathrm{cm}$, it can be concluded that the spring is only fed by the upper aquifer.

From the above data it can be concluded that the salt content of the groundwater is generally much higher than that of the lake water. There are considerable variations in the salt content of the groundwater within the same aquifer, but, generally speaking, there are clear indications of an increase in salinity from the north to the south and south-east of the polder.

It is very difficult at the present moment to predict the future salt content of the seepage water. It can, however, be stated, with all proper reserves, that it is not beyond the realms of possibility that the seepage water will become less saline after 10 to 50 years.

In order to ascertain the amount of salt supplied to the polder by seepage flow, it should be noted that the mean salt concentration of the groundwater at a depth of approximately $10 \mathrm{~m}$ in the elongated narrow westerly zone, through which 70 to $80 \%$ of the total seepage supply enters the polder, amounts to 650 micromhos $/ \mathrm{cm}$. For the remaining part of the polder the mean salt concentration of the groundwater in this upper aquifer is 1600 micromhos $/ \mathrm{cm}$.

If we give the seepage zone a weight analogous to the above mentioned percentage of 80 , the average salt concentration of the seepage water will be about 800 micromhos $/ \mathrm{cm}$.

\subsubsection{Chemical composition}

To investigate the factors which cause the salinity of the ground water, the concentrations of the important ions $\left(\mathrm{Ca}, \mathrm{Mg}, \mathrm{K}, \mathrm{HCO}_{3}, \mathrm{SO}_{4}\right.$ and $\left.\mathrm{Cl}\right)$ were determined in 17 samples. The results of these chemical analyses, expressed in milliequivalents per litre, are shown in Table 2. 
TABLE 2

Chemical compositions of the groundwater

\begin{tabular}{|c|c|c|c|c|c|c|c|c|c|c|c|c|c|}
\hline \multirow[t]{2}{*}{ Well } & \multirow{2}{*}{$\begin{array}{l}\text { Depth } \\
\text { in } m\end{array}$} & \multirow[t]{2}{*}{$\mathrm{EC} \times 10^{6}$} & \multicolumn{8}{|c|}{ Milliequivalents per litre } & \multirow[t]{2}{*}{ SAR } & \multirow{2}{*}{$\begin{array}{l}\text { "Residual } \\
\mathrm{Na}_{2} \mathrm{CO}_{3} "\end{array}$} & \multirow[t]{2}{*}{$\mathrm{pH}$} \\
\hline & & & $\mathrm{Ca}$ & $\mathrm{Mg}$ & $\mathrm{Na}$ & $\mathrm{K}$ & $\mathrm{CO}_{3}$ & $\mathrm{HCO}_{3}$ & $\mathrm{SO}_{4}$ & $\mathrm{Cl}$ & & & \\
\hline P8 & 2 & 729 & 5.80 & 1.73 & 2.30 & 0.40 & - & 8.92 & 0.48 & 0.11 & 1.2 & 1.4 & 7.4 \\
\hline P16 & 2 & 1430 & 6.90 & 1.48 & 3.10 & 0.40 & - & 8.88 & 2.52 & 0.22 & 1.5 & 0.5 & 7.2 \\
\hline P16 & 10 & 2490 & 12.70 & 3.54 & 8.90 & 0.40 & - & 11.52 & 13.50 & 0.42 & 3.2 & 0 & 7.6 \\
\hline P29 & 15 & 1095 & 0.90 & 0.25 & 7.0 & 0.20 & - & 6.16 & 0.73 & 1.18 & 9.2 & 5.0 & 7.8 \\
\hline $\mathrm{P} 26$ & 10 & 1505 & 3.40 & 0.99 & 12.80 & 0.20 & - & 14.62 & 1.73 & 0.76 & 8.6 & 10.2 & 7.5 \\
\hline $\mathrm{T} 3$ & 10 & 3660 & 11.30 & 1.07 & 16.70 & 0.90 & - & 3.68 & 24.5 & 2.39 & 6.7 & 0 & 7.5 \\
\hline $\mathrm{T} 3$ & 50 & 5650 & 27.0 & 4.18 & 4.60 & 0.90 & - & 29.98 & 1.08 & 4.05 & 1.2 & 0 & 7.7 \\
\hline $\mathrm{T} 2^{\mathrm{IV}}$ & 38 & 902 & 5.35 & 1.23 & 4.0 & 0.40 & - & 8.06 & 2.86 & 0.31 & 2.2 & 1.5 & 7.7 \\
\hline $\mathrm{T} 1$ & 31 & 125 & 1.55 & 0.25 & 0.3 & 0.10 & - & 1.62 & 0.38 & 0.11 & 0.3 & 0 & 7.2 \\
\hline $\mathrm{T} 4$ & 10 & 3125 & 2.55 & 13.20 & 31.60 & 0.50 & - & 38.40 & 7.58 & 0.42 & 11.3 & 22.6 & 7.8 \\
\hline $\mathrm{T} 4$ & 50 & 1650 & 2.14 & 1.40 & 5.80 & 0.70 & - & 7.60 & 2.35 & 0.76 & 4.3 & 4.1 & 7.6 \\
\hline \multicolumn{2}{|c|}{ Spring (near T4) } & 3000 & 1.95 & 0.15 & 38.5 & 0.30 & - & 34.88 & 4.14 & 1.50 & 37.7 & 32.8 & 7.9 \\
\hline T5 & 55 & 368 & 2.40 & 0.49 & 1.60 & 0.40 & - & 4.40 & 0.27 & 0.06 & 1.3 & 1.5 & 7.4 \\
\hline $\mathrm{P} 2$ & 43 & 259 & 1.95 & 0.08 & 1.10 & 0.20 & - & 2.68 & 0.33 & 0.21 & 1.1 & 0.7 & 7.3 \\
\hline P10 & 22 & 1392 & 5.60 & 0.82 & 5.30 & 0.40 & - & 11.68 & 0.46 & 0.20 & 3.0 & 5.3 & 7.7 \\
\hline P10 & 31 & 555 & 0.70 & 0.08 & 4.80 & 0.20 & - & 3.74 & 1.35 & 0.28 & 7.7 & 3.0 & 7.5 \\
\hline Lake & - & 107 & 0.80 & 0.08 & 0.30 & 0.10 & - & 1.10 & 0.13 & 0.14 & 0.5 & 0.2 & 7.0 \\
\hline
\end{tabular}


A hydrogeological classification*), for which the trilinear diagram proposed by Piper ${ }^{25}$ ) has been used shows the following types of groundwater (Fig. 11):

- nine analyses in the left part of the diagram all representing calcium bicarbonate water (secondary alkalinity);

- six analyses in the lower part of the diagram all representing water high in sodium and bicarbonate (primary alkalinity);

- two analyses in the central part of the diagram (P16 and T3) increasing in sodium and sulphate contents from left to right.

It appears that the present chemical composition of the groundwater has not been affected by sea-water contamination from previous marine transgressions, such as is known in the case of the Cretaceous, because all samples show low concentrations of chloride and generally high concentrations of bicarbonate.

Part of these samples represent calcium bicarbonate water. The calcium bicarbonate in this water probably originates from a normal solution of the cementing material and calcium carbonate concretions which frequently occur in the sands of the aquifers, especially in the lower aquifer.

\subsubsection{Suitability of groundwater for irrigation purposes}

A classification of the groundwater which is more relevant for irrigation purposes is based on the following characteristics ${ }^{27,9}$ ):

- electrical conductivity (EC), indicating the total concentration of soluble salts;

- sodium adsorption ratio (SAR value) expressed as follows:

$$
\mathrm{SAR}=\frac{\mathrm{Na}^{+}}{\sqrt{\frac{\mathrm{Ca}^{++}+\mathrm{Mg}^{++}}{2}} .}
$$

This ratio is an index of the hazard of the adsorption of sodium to the exchange complex of the soil if the water is used as irrigation water;

- residual $\mathrm{Na}_{2} \mathrm{CO}_{3}=\left(\mathrm{CO}_{3}^{\prime \prime}+\mathrm{HCO}_{3}^{\prime}\right)-\left(\mathrm{Ca}^{++}+\mathrm{Mg}^{++}\right)$.

If much bicarbonate is present, $\mathrm{Ca}$ and $\mathrm{Mg}$ tend to precipitate as carbonates if the soil solution becomes more concentrated by evapotranspiration. The relative concentration of sodium increases and, as a result, adsorption of sodium to the soil complex is likely to increase.

*) It should be borne in mind that this method of classification is based on percentage composition rather than on total amount of dissolved solids. 


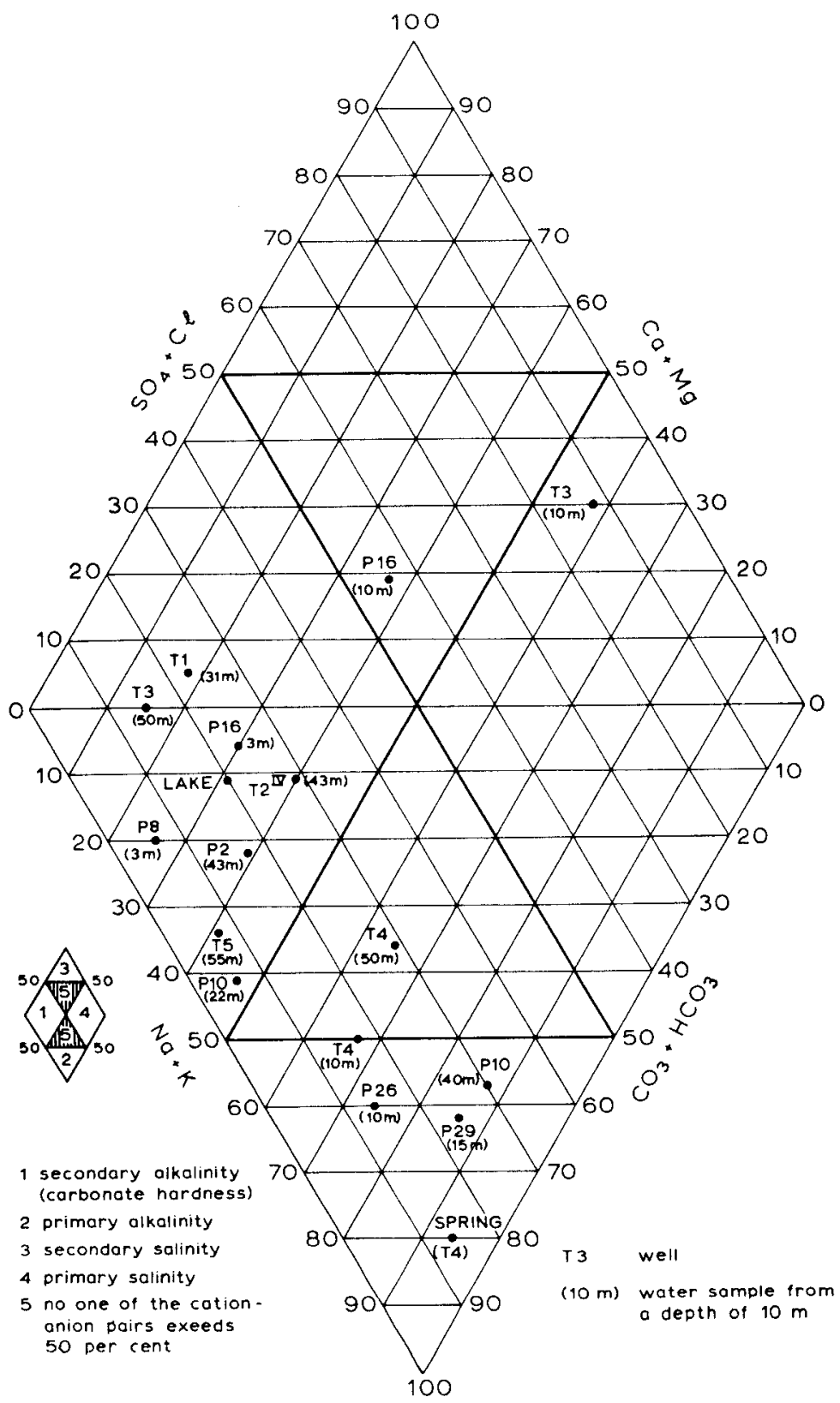

Fig. 11. Chemical composition of groundwater. 
The values of these characteristics for 17 groundwater samples are given in Table 2. As stated in the foregoing, the mean concentration of soluble salts in the seepage water amounts to $800 \mathrm{micromhos} / \mathrm{cm}$, i.e. approximately 500 parts per million.

According to generally accepted standards, this water is suitable for irrigation purposes, provided that possibilities exist for the periodic leaching and discharge of the percolation water.

A high SAR value of 38 was found in the spring water near well T4. The concentration is as high as 3000 to $4000 \mathrm{micromhos} / \mathrm{cm}$. This water may be considered unsatisfactory for irrigation purposes. All other samples have low SAR values, which indicates that there is no danger of an increasing adsorption of sodium to the soil complex.

In seven samples the residual $\mathrm{Na}_{2} \mathrm{CO}_{3}$ was found to be higher and, in some cases, considerably higher than $2.5 \mathrm{meq} / \mathrm{litre}$. This water seems less suitable or even dangerous for irrigation. The remaining samples show lower values, and there appears to be no risk when used as irrigation water.

Thus it appears that at several places in the polder the groundwater is suitable for irrigation purposes. In other parts, such as in the south, groundwater has to be considered less suitable and, in some cases, unsuitable.

\subsection{SOIL SALINITY}

It has already been seen that salt is introduced with the seepage water into the soil layers above the resistance layer, particularly, to the root zone of the crops. Evaporation occurs in this zone and the salt is left as the residue. By means of shadoof irrigation and also as a result of rainfall, a part of the accumulated salt is leached, which results in a higher salt concentration in the groundwater. A capillary rise from this enriched groundwater again leads to a greater accumulation of salt, etc.

Since there is at the present time no discharge of water from the polder and, therefore, no discharge of salt, the total accumulation of salt is directly related to the quantity and salt concentration of the seepage water. As a result of a number of factors, such as the earlier mentioned flow of seepage water from west to east in the surface soil, variations in elevation, local shadoof irrigation, differences in relative groundwater level and the local supply of seepage water with an abnormal salt concentration, the distribution of the salt introduced is very uneven. On the one hand, there are parts of the polder, particularly a western border zone, where salinization is of little importance. On the other hand, there are parts where salt accumulation is already so great that a crop can no longer grow there. Between 
these two extremes there are many parts where salt damage already occurs to a greater or lesser extent.

A little less than half the polder is reed-covered. The inaccessibility of this part of the polder makes it difficult to give a clear assessment of the salt content at this particular location. Incidental observations (P16, P17, P25, P25A), however justify the assumption that the reed-covered area is highly salinized.

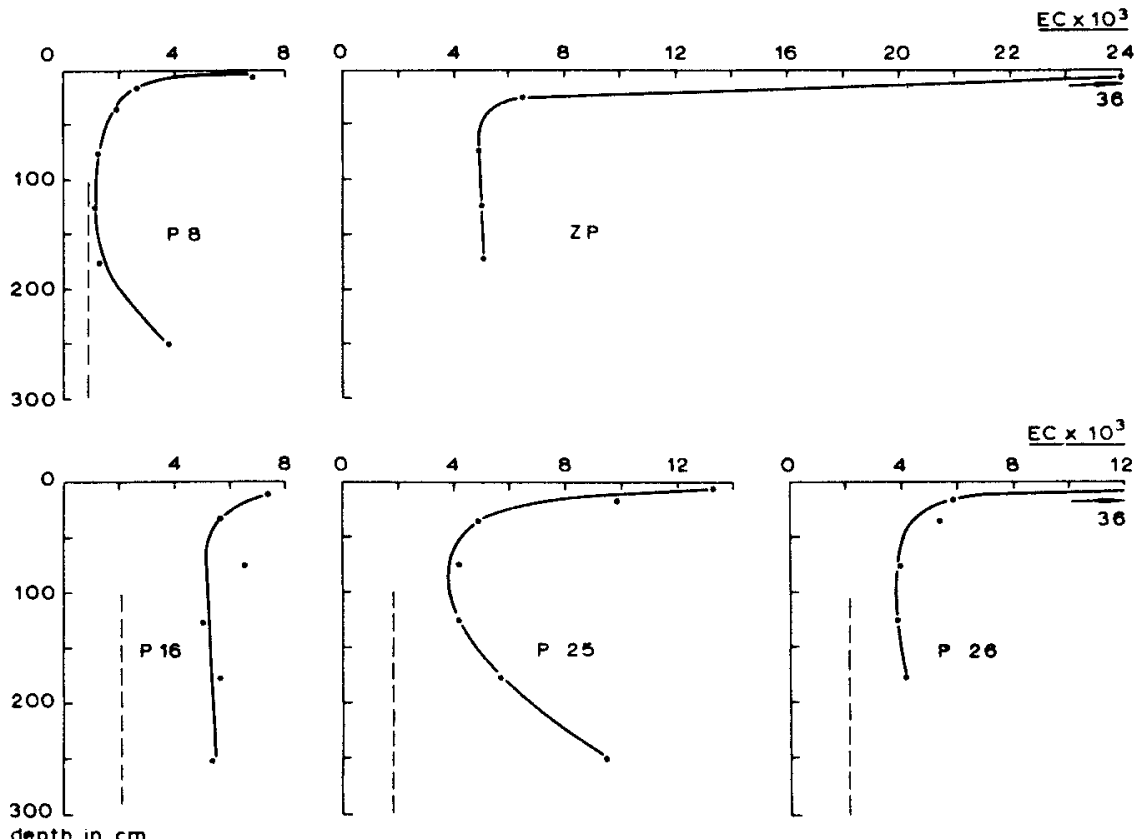

depth in $\mathrm{cm}$

Fig. 12. Salt distribution (electrical conductivity of the saturation extract) of some soil profiles.

-....- ground water salinity.

Fig. 12, which illustrates five points in the polder, gives the results of salt samples taken from the soil to a depth of 2 to $3 \mathrm{~m}$ below the surface*). It can be seen that the salt content does not decrease at any of the five points in the deeper soil layers. On the contrary, points P8 and P25 show a sharp increase in salt content in the layers which are more than $150 \mathrm{~cm}$ below the surface. At P16 this increase is much less pronounced, whilst the curves of P26 and ZP are inconclusive. P8 shows the lowest salt contents in the

*) The soil layers concerned were all sampled at nine separate locations within an area of $10 \mathrm{~m}^{2}$. The curves show the average result. 
$0-150 \mathrm{~cm}$ section. The wheat here grew very well; shadoofs provided the water. ZP (east side of the polder opposite the Matafo garden) has a particularly salty top soil. Although wheat was still being sown here and there in the area, there was no question of a crop. Points P16 and P25 are situated in the reed-covered area. The soil there is as salty as, and, in some cases, saltier than that at ZP. Finally, P26 has a very salty top soil. The quality of the wheat here was very poor; the soil had not been irrigated.

The amount of sodium adsorbed to the exchange complex was low at P8 and P16 and high at ZP, P25 and P26. Expressed as percentages of the total quantity of cations adsorbed these amounts were $10,17,30,30$ and 45 per cent, respectively, in the top $20 \mathrm{~cm}$ of soil. In the deeper layers the percentages were somewhat lower, although they did not drop below 20 in the sampled layers of $\mathrm{P} 25$ and P26. The pH ranges from 7.5 to 8.5 in the top $20 \mathrm{~cm}$ and, owing to the large quantity of soluble salts, the structure of the top soil is good to excellent. Leaching may, however, cause some dispersion of soil particles if calcium ions do not become available at a sufficient rate.

In Fig. 12 the salt content of the groundwater at the sampling points is also shown. The water samples were taken from piezometers (filters from 1 to $2 \mathrm{~m}$ below the surface) and uncased wells (extending to the resistance layer) at various intervals during a pumping test. Obviously, there is no equilibrium between soil and water, which is probably due to the presence of large fissures. We may therefore assume that no equilibrium exists between groundwater (in the fissures) and soil moisture (in the soil units bordered by fissures).

The available data are not sufficient to explain why the salt content of the groundwater appears to be lower than that of the saturation extract of the soil.

\section{The salt and water regime}

In the discussion of the nature of the groundwater flow it has been shown that water flows from the lake towards the polder through the subsoil. Owing to the partial or complete absence of the resistance layer at the basis of the upper clay series in the western border zone, the seepage water enters here from the aquifers into the seepage zone and flows in an easterly direction through the fissured clay which is found between the resistance layer and the root zone of the crops.

The quantity of flow amounted to some $5.4 \mathrm{~mm} /$ day in the latter half of March 1963. To characterize the water regime, however, data for other periods are also required. These data have been ascertained from a water balance. 
The seepage water contains about $500 \mathrm{mg}$ of salt per litre. This amount is carried to the upper soil layers and, since there is no natural drainage, remains as a residue in the root zone of the crops after evaporation and transpiration. The present rate of salinization and desalinization, which is decisive for future land use in the polder, will be discussed in the light of a salt balance. Such a balance has been prepared for the whole of the polder, for which the groundwater tables quoted in line 2 of Table 3 are assumed to be valid. Consequently, neither the extreme northern and southern parts nor the more elevated border zones comply with the computation pattern.

It appears that the difference between the groundwater table and the level of Lake Chad varies between 3.60 and $4.80 \mathrm{~m}$ (Table 3, lines 1, 2 and 3 ). The investigations discussed in this paper, which were carried out in March, relate to a period of great differences, i.e. when there was a relatively steep hydraulic gradient.

The monthly seepage supply is obtained from the annual total of $2000 \mathrm{~mm}$, as ascertained from Section 6, by apportioning the total according to the available heads shown in line 3 . For reasons of simplicity a steady state flow is assumed for each month. The values shown in line 3 are therefore assumed to represent the monthly average.

The seepage varies from $135 \mathrm{~mm}$ in August to $180 \mathrm{~mm}$ in the period January-May and is therefore on the high side for March.

If the salt concentration of the seepage water is $800 \mathrm{micromhos} / \mathrm{cm}$ (line 7), then the amounts of salt shown in line 8 are supplied to the upper $50 \mathrm{~cm}$ of soil (see also the relative water tables in line $2 \mathrm{~A}$ ). The total salt accumulation appears to amount to 0.2 grams of salt per 100 grams of dry soil and per year. This means that the crop yields will already show considerable reductions after 3 to 5 years of salt accumulation.

Some $40 \mathrm{~mm}$ of the $300 \mathrm{~mm}$ of annual rainfall percolated through the root zone (i.e. below the level of $50 \mathrm{~cm}$ below the surface of the soil into the underlying layer). As a result the water table has risen to the $50 \mathrm{~cm}$ level and additional rainfall will cause only a certain salt movement within the upper $50 \mathrm{~cm}$ of soil.

It will be obvious that the degree of desalinization which may be calculated from a $40 \mathrm{~mm}$ percolation does not actually take place in the field. Since no water can be drained out of the polder area, the salts leached will return to the surface. Owing to the west-east groundwater flow, such a return will not occur at the same location, but somewhat more to the east. Consequently, the concentration of the capillary rising water will vary considerably in an easterly direction, which, in turn, will cause differences in local accumulation of salt.

An important exception to this accumulation pattern is found in the western border zone. As previously observed, this zone has a more elevated 
TABLE 3

Water and salt balance

Oct. Nov. Dec. Jan. Feb. March April May June July Aug. Sept. Total average

1. Water level of Lake

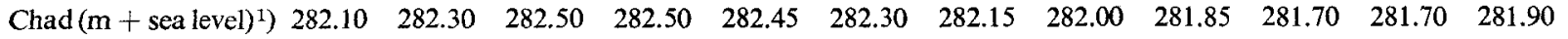

2. Average groundwater

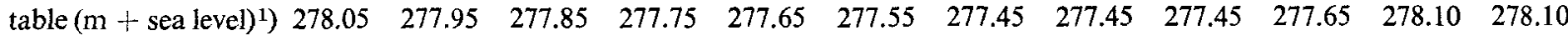

2A. Average ground-

water table, in $\mathrm{m}$ be-

3. Difference between the

levels 1 and 2 , in $m$

4. Precipitation, in $\mathrm{mm}^{2}$ )

5. Seepage supply, in mm

per month
$5 \mathrm{~A}$. Seepage supply, in

6. Evapotranspiration,

in $\mathrm{mm}^{3}$ )

7. Salt concentration of seepage water, in mmhos/cm

$\begin{array}{lllllllllllll}155 & 165 & 175 & 180 & 180 & 180 & 180 & 175 & 165 & 155 & 135 & 145 & 1990\end{array}$

8. Salt supply to the root zone, in $\mathrm{g}$ per $100 \mathrm{~g}$ of dry soil $\left.{ }^{4}\right)$

1) Derived from Pias and Barbery ${ }^{22}, 23$ ). Years with exceptional levels have been left out of consideration.

2) Average of $1946-1960$.

3) Assessed from lines 2, 4 and 5 (natural drainage being absent). The porosity of the upper $25 \mathrm{~cm}$ of soil is taken at $33 \%$, that of the $25-65 \mathrm{~cm}$ layer at $25 \%$, the difference being partly due to variation in organic matter content.

4) Accumulation in the upper $50 \mathrm{~cm}$ of soil, for which the apparent specific gravity amounts to 1. 
position, which implies a deeper water table. Here, water is applied to the crops by means of shadoof irrigation. Owing to overirrigation, accumulated salts are leached into the groundwater and are transported out of the zone by a horizontal easterly flow. In these western border regions a natural drainage occurs which ensures the evacuation of leached salts. This condition will protect the region from salinization or, at any rate, salinization will be retarded considerably if adequate irrigation is continued. The same is more or less true of some parts of the polder near the $\mathrm{A}-\mathrm{A}^{\prime}$ grid line, which also have a higher elevation.

\section{Final remarks}

With regard to the polder as a whole, the following final remarks may be made.

What appeared at first sight to be a good natural balance between the water supplied by seepage and the water requirements for rather intensive crop growing has in fact proved to be a balance of a very delicate nature. The removal of salts is a prerequisite to maintaining agriculture at its present level and even to cultivation in general. Any solution to the salt problem has to comprise the lowering of the groundwater table, which involves artificial drainage, including a pumping station to lift the water over the dunes. This in itself will also serve the purpose of preventing the creation of saturated conditions in the root zone during rainy periods. A lowering of the water table will, however, result in the upsetting of the existing balance between inflow and consumption of water. The amount of seepage water will probably increase and the need for an additional water supply will arise if the irrigated acreage expands. These problems are at present being studied.

It should be pointed out that any prediction with regard to the future incidence of salt rests on the assumption that the salt content of the seepage water is a constant. It is indeed believed that this salt content will not be subject to significant changes in the near future.

Finally, the seepage flow supporting the impressive growth of crops in parts of this region depends for its intensity on the transmissibility of the aquifers and on the potential gradient available for flow through the stretch of dune between the lake and the polders. Any extension of the polders as a result of the enclosure of adjacent lake inlets or interdunes will result in a considerable change in the intensity of stream flow to the existing polders. The seepage will diminish roughly in proportion to the increase in distance between the polder and the lake. It is for this reason that any contemplated extension of the polder areas should be considered very carefully. 
Abstract: Hydrogeological investigations of an area on the northern shore of Lake Chad revealed an intricate pattern of groundwater flow from the direction of the lake towards and into low-lying cuvettes or polders. The seepage flow is sufficient to balance the consumptive use of crops, but the quality of the seepage water is such that the polders are threatened with complete salinization.

In this article methods of investigation of the hydrological conditions are discussed and the gradual development of salinity in the cultivated areas is analysed. 


\section{References}

1) L. Balot, Pluviaux interglaciaires et préhistoire saharienne. Travaux de l'Institut de Recherches sahariennes, Alger, VIII (1952) 9-22

2) J. Barbeau, Quaternaire des abords orientaux du Lac Tchad. C. R. Soc. Géol., Fr. 5 (1959)

3) W. F. J. van Beers, The Auger-Hole Method. Bull. 1'Inst. Intern. pour l'Amélioration et la Mise en Valeur des Terres. Wageningen, Hollande (1958) $32 \mathrm{p}$.

4) C. G. Bossière, L'avenir du Lac Tchad. La Nature, 2963 (1935) 337-339

5) A. Bouchardeau, Etudes d'évaporation dans les régions sahelosoudaniennes. Publ. No. 45 de l'Assoc. Intern. d'Hydrologie Scient. Gentbrugge, III (1958) 407-420

6) - and R. Lefèvre, Monographie du Lac Tchad, I. Edition provisoire de l'Office de la Recherche Scient. et Techn. Outre-Mer (1957) $112 \mathrm{p}$.

7) R. Capot-Reij, Les limites du Sahara français. Travaux de l'Institut de Recherches sahariennes, Alger, VIII (1952) 23-48

8) F. Dubief, Le vent et le déplacement du sable au Sahara. Travaux de l'Institut de Recherches sahariennes, Alger, VIII (1952) 123-164

9) F. M. Eaton, Significance of Carbonates in Irrigation Waters. Soil Sci. 69 (1950) 123-133

10) $\mathrm{H}$. Erhart, Sur la nature minéralogique et la génèse des sédiments de la cuvette tchadienne. C. R. Acad. Sciences, Paris 237 (1953) $401-403$

11) L. F. Ernst, Grondwaterstromingen in de verzadigde zone en hun berekening bij aanwezigheid van horizontale evenwijdige open leidingen (Groundwater flow in the saturated zone and its calculation when horizontal parallel open conduits are present) with a summary in English, (Thèse Utrecht 1962) $189 \mathrm{p}$.

12) H. Franz, Boden- und wasserwirtschaftliche Probleme im Tschadgebiet. Oesterreichische Wasserwirtschaft 10 (1958) 48-51

13) R. Furon, The Geology of Africa (Edinburgh and London, 1963)

14) G. J. De Glee, Over grondwaterstroming bij wateronttrekking door middel van putten. Thèse (Delft, 1930) $175 \mathrm{p}$.

15) —_ Berekeningsmethoden voor de winning van grondwater. 3e Vacantiecursus, 4-5 Januari 1951, Den Haag, 38-80

16) E. Guichard, G. Bouteijre and B. Lepoutre, Etude pédologique des polders de Bol et Bolguini. Office de la Recherche Scient. et Techn. Outre-Mer (1959) 69 p. 
17) M. S. Hantush, Analysis of Data from Pumping Tests in Leaky Aquifers. Trans. Amer. Geoph. Union 37 (1956) 702-714

18) J. Pias, Transgression et régression du Lac Tchad à la fin de $1^{\text {ere }}$ tertiaire et au quaternaire. Monographie du Lac Tchad I (1957) by A. Bouchardeau et R. Lefèvre, p. 36

19) —-, Essai de classification des sols de la cuvette tchadienne. Publ, No. 50, Com. Coop. Techn. en Afrique au Sud du Sahara I (1959) 441-447

20) J. Pias and E. Guichard, Origine et consequences de l'existance d'un cordon sableux dans la partie Sud-Ouest de la cuvette tchadienne. C. R. Acad. des Sciences, Paris 244 (1957) 791-793

21) —_, Etude pédologique des rives du Lac Tchad de Djimtilo à Bol. Publ. No. 50, Com. Coop. Techn. en Afrique au Sud du Sahara I (1959) 449-456

22) J. Pias and J. Barbery, Evolution de la salinité dans le polder de Bol Guini en 1959 et 1960. Office de la Recherche Scient. et Techn. Outre-Mer (1960) $106 \mathrm{p}$.

23) —_, Evolution de la salinité dans le polder de Bol Guini. Publ. No. 61-58, Office de la Recherche Scient. et Techn. Outre-Mer (1961) 58 p.

24) J. Pias, E. Guichard, G. Bouteijre and B. Lepoutre, Caractéristiques générals des sols des polders du Lac Tchad et problèmes de leur mise en valeur. Publ. No. 50, Com. Coop. Techn, en Afrique au Sud du Sahara I (1959) 265-277

25) A. M. Piper, A Graphic Procedure in the Geochemical Interpretation of Wateranalyses. Trans. Amer. Geoph. Union (1944) 914-929

26) Th. Regout, Een merkwaardige aantapping in het stroomgebied van het Tsjaadmeer. Tijdschr. Kon. Nederl. Aardr. Gen. 58, 2e serie (1941) 1012-1024

27) L. A. Richards, Diagnosis and Improvement of Saline and Alkali Soils. Agriculture Handbook No. 60, U.S. Dept. of Agriculture (Washington, 1954) 160 p.

28) H. Schoeller, Les eaux souterraines (Paris, 1962) $642 \mathrm{p}$.

29) SOGETHA Report, Etude d'un polder expérimental dans la région de Bol. Etudes préliminaires (Paris) $139 \mathrm{p}$.

30) G. J. Tilho, Sur l'aire probable d'extension maxima de la mer Paléotchadienne C. R. Acad. Sciences. Paris CLXXXI (1925) 643-646 